\title{
Transient GUS and GFP Expression in Spanish Red Cedar (Cedrela odorata L.) Somatic Embryos. Optimization of Bombardment Conditions and Evaluation of Selective Agent Lethal Dose
}

\author{
Yuri J. Peña-Ramírez ${ }^{1 *}$, Max M. Apolinar-Hernández ${ }^{1}$, Oscar A. Gómez-y-Gómez ${ }^{1}$, \\ Luisa A. López-Ochoa ${ }^{2}$, Aileen O’Connor-Sánchez ${ }^{2}$ \\ ${ }^{1}$ Instituto Tecnológico Superior de Acayucan, Acayucan, México \\ ${ }^{2}$ Centro de Investigación Científica de Yucatán, Mérida, México \\ Email: *yuri.pena@gmail.com
}

Received October $2^{\text {nd }}, 2011$; revised January $14^{\text {th }}, 2012$; accepted January $21^{\text {st }}, 2012$

\begin{abstract}
Cedrela odorata is a tropical tree widely appreciated for its wood. Commercial plantations are frequently hampered by the attack of the meliacea borer, Hypsipyla grandella, and the lack of resistant varieties. $C$. odorata traditional breeding would consume very long periods of time, thus direct transfer of entomotoxic coding genes to generate resistant varieties is a promising alternative. There are two prerequisites for gene manipulation of this species: 1) to set the conditions for transgene delivery and 2) to have a way to select regenerating transformed plants. In this paper, we report the optimal biolistics conditions for transient expression of uidA and $g f p$ reporter genes in C. odorata somatic embryos and the selective doses for kanamycin, spectinomycin, phosphinotrycin and hygromycin to screen transformed cells.
\end{abstract}

Keywords: Biolistics; Genetic Transformation; Tree Genetic Modification; Tropical Wood

\section{Introduction}

The establishment of commercial plantations of some tropical hardwood species native to the Americas, such as Spanish red cedar (Cedrela odorata), mahogany (Swietenia macrophylla), and ipé (Tabebuia spp.), among others, faces serious limitations because of the lack of domesticated varieties able to sustain cultivated plantations (Merkle \& Nairn, 2005). C. odorata (Meliaceae) is the second most valued wood tropical product, thus it has a huge economical importance as a crop, however, its high susceptibility to the attack of the borer Hypsipyla grandella (Lepidoptera: Pyralidae) has hindered the efforts to grow this species as a managed crop (Pérez-Salicrup \& Esquivel, 2008). Among all the existing strategies for C. odorata improvement, breeding through modern genetic manipulation remains to date a pending issue. Direct transfer of a desirable gene into the trees could generate novel traits without any significant modification of their genetic background, one of those traits could be pest resistance (Campbell et al., 2003). Gene manipulation of tree species has already been employed as a tool for basic studies, for manipulation of lignin/cellulose content, for improving wood quality or kraft pulping, for modification of flowering time and tree architecture, to confer abiotic stress tolerance, and for developing pest-resistant tree varieties (Giri et al., 2004)

In order to move forward to the genetic manipulation of $\mathrm{C}$. odorata, our group has recently developed an efficient regeneration system of juvenile material via somatic embryogenesis using immature zygotic embryos as initial explants (Peña-

${ }^{*}$ Corresponding author.
Ramírez et al., 2011). However, to establish a reliable gene transfer protocol, it is also necessary to find an efficient gene transfer procedure and a methodology to select transformed cells. Nowadays, gene transfer mediated by biolistic bombardment is a widely used tool, though the efficiency of this procedure varies depending on a number of physical and biological factors, such as the amount of DNA loaded onto the projectiles, the projectile's speed, their size and density (Sanford et al., 1993), the helium pressure used (Able et al., 2001; Casas et al., 1993; Ikea et al., 2003; Tadesse et al., 2003), the target explant characteristics, and the osmotic pressure in the medium (Klein \& Jones, 1999). Therefore, the optimum efficiency of heterologous DNA transfer into plant cells can only be achieved by a fine balance between the factors involved in bombardment efficiency and factors related to target-tissue damage (Tadesse et al., 2003; Zuker et al., 1995). Optimizing these conditions is frequently a tedious and time consuming issue, mainly when a stable expression of the genes used for detection and selection is required. These limitations can be circumvented by assessing transient expression of reporter genes, allowing almost immediate detection of transformed cells (Hunold et al., 1994). Transient expression assays have proven useful to find the optimal conditions for transformation (Able et al., 2001; Heim \& Tsein, 1996; Jeoung et al., 2003). The genes that are most frequently employed as reporters for transient gene expression are: 1) the bacterial gene uidA (GUS) coding for $\beta$-glucuronidase, which catalyses the hydrolysis of X-Gluc (Jefferson et al., 1987), and 2) the $g f p$ gene coding for the green fluorescent protein (GFP) cloned from jellyfish Aequorea victoria (Elliott et al., 1999), which allows a simple detection by visualizing its expression in 
intact tissues, without adding exogenous substrates. In addition to an optimized DNA-delivery system, to achieve a successful plant transformation requires an efficient selection of the transformed cells, to allow only the regeneration of transgenic plants, preventing the proliferation of non-transformed sectors (PérezBarranco et al., 2009). The main goals in the present work were to optimize the conditions to transform C. odorata somatic embryos by biobalistics, using transient expression of uidA and $g f p$ as reporter genes, and to determine the inhibitory doses of four selective agents to be used for T0 plant selection. Both achievements will lead to the establishment of an efficient $C$. odorata transformation protocol.

\section{Materials and Methods}

\section{Plant Material}

Embryogenic calluses were initiated and maintained according to the methodology previously reported by our group (PeñaRamírez et al., 2011). For biolistic experiments, calli were subcultured one week prior to transformation. Each shoot was performed over approximately $0.1 \mathrm{~g}$ of embryogenic calli type II-A located inside of a $3 \mathrm{~cm}$-diameter circle at the center of petri dishes containing full-strength MS (Murashige and Skoog 1962) medium, $80 \mathrm{mM}$ sucrose, $13.4 \mu \mathrm{M}$ dicamba and $2.5 \%$ (w/v) GelRite $\AA$ (PhytoTechnology Laboratories, Lenexa, KS), $\mathrm{pH}$ 5.7. For lethal-dose experiments, $0.2 \mathrm{~g}$ of embryogenic clusters were spread in each Petri dish containing the same basal medium supplemented with the appropriate antibiotics (see below).

\section{Plasmid Preparation and Biolistics}

The plasmids pCAMBIA1201 and pCAMBIA1302 (www. cambia.org) carrying either uidA or $g f p$ gene driven by the constitutive CaMV $35 \mathrm{~S}$ promoter, previously cloned in E. coli DH5 $\alpha$ F', were extracted using QIAGEN (Germantown, MD) Maxi Prep kits. The concentration of the plasmid DNA was calculated using a spectrophotometer (SmartSpec, BioRad, Hercules, CA). Embryo bombardment was carried out using a PDS-1000/He Biolistic Particle Delivery System (BioRad). The plasmid DNA was coated onto gold particles as described by the manufacturer (BioRad). Six microlitres of the DNA-microcarrier suspension (see Table 1) were dispensed onto each macrocarrier membrane and allowed to dry. The standard bombardment procedure was performed using manufacturer's instructions. In the first treatment, variables were set as follows: $6 \mathrm{~cm}$ of shooting distance, $1 \mu \mathrm{m}$ particle diameter, $6 \mu \mathrm{g}$ of DNA, $0.1 \mathrm{M}$ spermidine, and vector pCAMBIA1302. To assess the subsequent parameters, further variables were set according to the optimal condition previously determined. Each treatment was repeated 3 times, each consisting of 5 shoots.

\section{Evaluation of GUS and GFP Transient Expression}

Transient expression was analyzed $36 \mathrm{hr}$ after bombardment. GUS assays were carried out using the protocol reported by Jefferson et al. (1987) with minor modifications. GUS expression was tested by immersing explants in 5-bromo-4-chloro-3indolyl- $\beta$-d-glucuronic acid (X-Gluc) buffer overnight, at $37^{\circ} \mathrm{C}$ in the dark, with a subsequent wash for $24 \mathrm{~h}$ in absolute ethanol. The number of blue spots (foci) on explants was observed un- der a stereomicroscope using a white light source. For GFP analysis, calli were observed under an Olympus microscope equipped with a GPP-2 filter and ultraviolet illumination source. For both systems, the number of foci per petri dish was quantified by analyzing digital photographs with the assistance of the software Quantity One ${ }^{\circledR}($ BioRad).

\section{Determination of Antibiotic Lethal Dose}

Wild type embryogenic calli were cultured on MS medium prepared as previously described and supplemented with different concentrations of Kanamycin (KAN) $(0.0,20.0,50.0$, $100.0,150.0,200.0,350.0,500.0$, or $750.0 \mu \mathrm{M})$; hygromycin (HYG) $(0.0,1.0,2.0,5.0,10.0,15.0,20.0,35.0$, or $50.0 \mu \mathrm{M})$; Spectinomycin (SPE) $(0.0,20.0,50.0,100.0,150.0,200.0$, $500.0,750.0$, or $1000.0 \mu \mathrm{M})$; or phosphinotricin (PPT) $(0.0,0.5$, $1.0,2.0,3.5,5.0,10.0,15.0,20.0,35.0$, or $50 \mu \mathrm{M}$ ) (PhytoTechnology Laboratories, Lenexa, KS). Antibiotics were filter-sterilized and added to the autoclaved medium at $45^{\circ} \mathrm{C} .10$ calli, $20 \mathrm{mg}$ each, were used for each treatment and the procedure was repeated 3 times. After three weeks, plant material was transferred to an antibiotic-free medium. Viability was assessed 3 weeks later as the ability of embryos to proliferate (measured as weight gain) on an antibiotic-free medium.

\section{Statistical Analysis}

Each parameter was evaluated by using an experimental sample of five Petri dishes and repeated twice. The data were analyzed using standard ANOVA procedures. The differences between the means were determined by Fisher's least significant difference (LSD) tested with the assistance of Statistica ${ }^{\circledR}$ software package (StatSoft, Tulsa, OK).

\section{Results and Discussion}

\section{Biolistic Optimization}

To find the optimal conditions for microparticle delivery, 16 treatments were analyzed, which involved different membrane rupture pressures, shooting distances, microcarrier diameters, plasmid DNA amounts, spermidine concentrations, and two pCAMBIA vectors. Treatment efficiency was evaluated by the number of transient expression foci produced. As can be seen in Table 1, the results show significant differences between the different pressures assayed. 1200 psi produced the best results, followed by 1600 and 900 psi. These acceleration pressures might be considered relatively high for this kind of explants, according to Rasco-Gaunt et al. (1999) who found that bombardment pressures over 900 psi cause a drastic drop in transient expression. However, other authors have reported similar results for transformation of embryogenic calli (Abdollahi et al., 2009; Tee \& Maziah, 2005).

Shooting distance also had a significant effect. $9 \mathrm{~cm}$ resulted the best, followed by 7.5 and $6 \mathrm{~cm}$; longer distances caused an abrupt decrease in the number of foci. Tee and Maziah (2005) and Abdollahi et al., (2009) have found that short distances combined with high shooting pressures might cause an increase in cell damage or injury, resulting in low regeneration rates. We observed this to happen in the case of $C$. odorata regeneration index, which was significantly affected in treatments 5, 6, and 7, where high shooting pressures were combined with short distances. In those cases the regeneration rate dropped by nearly 
Table 1.

Optimization of biolistic parameters.

\begin{tabular}{|c|c|c|c|c|c|c|c|}
\hline Treatment & $\begin{array}{l}\text { Membrane rupture } \\
\text { pressure (psi) }\end{array}$ & $\begin{array}{l}\text { Shoot distance } \\
(\mathrm{cm})\end{array}$ & $\begin{array}{c}\text { Microcarrier } \\
\text { diameter }(\mu \mathrm{m})\end{array}$ & DNA amount $(\mu \mathrm{g})$ & $\begin{array}{l}\text { Spermidine } \\
\text { addition }\end{array}$ & pCambia vector & $\begin{array}{l}\text { Number of foci/ } 100 \mathrm{mg} \\
\text { of embryogenic calli }\end{array}$ \\
\hline 1 & 400 & 6 & 1 & 6 & + & 1302 & $21.0 \pm 1.1^{c}$ \\
\hline 2 & 600 & 6 & 1 & 6 & + & 1302 & $28.6 \pm 1.9^{d}$ \\
\hline 3 & 900 & 6 & 1 & 6 & + & 1302 & $49.4 \pm 1.5^{e}$ \\
\hline 4 & 1100 & 6 & 1 & 6 & + & 1302 & $49.2 \pm 1.0^{f g}$ \\
\hline 5 & 1550 & 6 & 1 & 6 & + & 1302 & $45.6 \pm 1.9^{e f}$ \\
\hline 6 & 1100 & 3 & 1 & 6 & + & 1302 & $15.0 \pm 2.0^{b}$ \\
\hline 7 & 1100 & 4.5 & 1 & 6 & + & 1302 & $19.6 \pm 1.5^{c}$ \\
\hline 8 & 1100 & 7.5 & 1 & 6 & + & 1302 & $56.0 \pm 1.4^{h}$ \\
\hline 9 & 1100 & 9 & 1 & 6 & + & 1302 & $60.6 \pm 2.6^{i}$ \\
\hline 10 & 1100 & 12 & 1 & 6 & + & 1302 & $12.4 \pm 2.4^{a b}$ \\
\hline 11 & 1100 & 9 & 0.6 & 6 & + & 1302 & $32.2 \pm 1.1^{d}$ \\
\hline 12 & 1100 & 9 & 1.6 & 6 & + & 1302 & $10.4 \pm 1.1^{a b}$ \\
\hline 13 & 1100 & 9 & 1 & 2 & + & 1302 & $32.2 \pm 0.9^{c}$ \\
\hline 14 & 1100 & 9 & 1 & 10 & + & 1302 & $67.2 \pm 0.7^{j}$ \\
\hline 15 & 1100 & 9 & 1 & 10 & - & 1302 & $8.8 \pm 1.2^{a b}$ \\
\hline 16 & 1100 & 9 & 1 & 10 & + & 1201 & $57.6 \pm 1.2^{h}$ \\
\hline
\end{tabular}

The average value of the number of foci per treatment is presented \pm Mean Standard Error. Cursive letters next to values correspond to significant difference levels by LSD test at $p \leq 0.05 ; n=5 \times 3$.

$50 \%$ (data not shown). With regard to particle size, the $1 \mu \mathrm{m}$ microprojectile resulted in the highest numbers of foci. Optimal results were obtained when $10 \mu \mathrm{g}$ of plasmid DNA were precipitated onto $2 \mathrm{mg}$ of gold particles. In contrast, spermidine depletion strongly decreased the number of foci, demonstrating its importance for the adequate adsorption of the plasmid onto the gold particle. These results coincide with the findings reported by Rasco-Gaunt et al., (1999), who reported a drop of uidA transient expression in samples without spermidine. Moreover, the differences observed between pCAMBIA plasmids 1302 and 1201 could be an effect of the image analysis, because fluorescent foci can be quantified more efficiently than blue ones. The lower contrast between expressed uidA foci and their background, as well as the difficulty to get spots arrangements in a single plane, making it hard to get good images for foci quantification (Schöpke et al., 1997) and therefore the analysis might be less sensitive. Nonetheless it can be concluded that both uidA and $g f p$ can be successfully used as reporter genes for transformation in C. odorata embryogenic calli (Figures 1(a)-(c)).

\section{Selective Dose Determination}

To determine a selective concentration of antibiotics useful to inhibit the proliferation of untransformed plant cells, four selective agents were evaluated cultivating $C$. odorata type II-A embryogenic calli in the presence of different concentrations of KAN, HYG, SPE and PPT. As shown in Figure 1(d), callus viability was affected by all the tested antibiotics following similar patterns. PPT was the most toxic agent, requiring a concentration of $5 \mu \mathrm{M}$ to kill $100 \%$ of calli, followed by $20 \mu \mathrm{M}$ $\mathrm{HYG}, 500 \mu \mathrm{M}$ SPE, and $1 \mathrm{mM}$ KAN. Similar concentrations have been reported to inhibit embryo regeneration of chestnut
(Rothrock et al., 2007), grape (Geier et al., 2008), oil palm (Parveez et al., 1997), Eucalyptus (Sartoretto et al., 2002) and poplar (Okumura et al., 2006). The obtained lethal doses could be considered as common for several plant species, however it was very important to establish them for $C$. odorata because sometimes even slight variations in the physiological conditions of a particular tissue or in its the genetic background may change its susceptibility to the toxicity of a given selective agent (Duke, 1996). Finally, it was observed a non linear susceptibility curve for all the tested antibiotics, which quickly drops to around $20 \%$ to $25 \%$ of survival, followed by a weaker slope to finally reach $0 \%$ of somatic embryo viability. A biphasic behavior has also been reported for other embryogenic cultures (Catlin, 1990; Parveez et al., 1997) and is in agreement with classic data for cell culture systems with high mitotic activity (Drewinko et al., 1974), thus it supports our previous observations that suggest an unsynchronized and highly proliferative nature of $C$. odorata embryogenic callus.

\section{Conclusion}

As far as we know, this work is the first report of an approach to establish a $C$. odorata gene manipulation protocol. The optimized set of biolistic parameters and the determination of lethal dosages for four antibiotics commonly used for selective screening of transformed plants, provide the necessary foundations for future efforts to generate improved varieties of C. odorata through modern genetic manipulation, including those resistant to $H$. grandella. Most of the previous work related with genetic modification of Meliacea has been constricted the genus Azadirachta (Morimoto et al., 2006) via Agrobacterium-mediated gene delivery. This work provides experimental data that could be used not only for $C$. odorata 

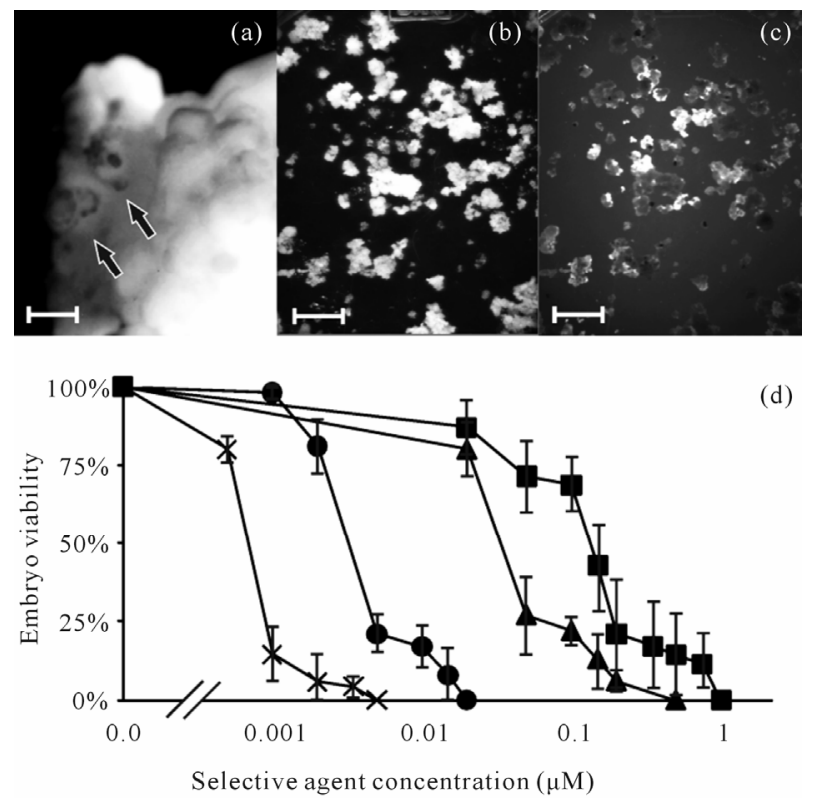

Figure 1.

Transient expression in embryogenic calli and lethality curves. Bombarded embryogenic calli expressing transient foci of GUS (a) or GFP under white (b) or UV light (c). Arrows in (a) point to foci clusters in a representative bombarded callus. The white bar in a) corresponds to a length of $50 \mu \mathrm{m}$ whereas in (b) and (c) it is equivalent to $1 \mathrm{~cm}$. d) shows the lethality curves of PPT $(\times), \operatorname{HIG}(\bullet), \operatorname{SPE}(\boldsymbol{\Delta})$, and KAN (•) measured as viability of $C$. odorata embryogenic callus cultured under several concentrations of selective agents. Bars at each point correspond to the Mean Standard Error.

manipulation, but also lay the foundations to generate transformed Meliacea trees of other genus via biolistic approach.

\section{Acknowledgements}

The authors thank to Virginia Herrera for training given to MMAH. Financial support provided by CONACYT-CONAFOR C03-10013; SEP-CONACYT C01-53851and ITSA-DIC 2004-1 is gratefully acknowledged. MMAH and GJTL thank CONACYT for undergraduate studentships.

\section{REFERENCES}

Abdollahi, M. R., Moieni, A., Salmanian, A. H., \& Mousavi, A. (2009). Secondary embryogenesis and transient expression of the $\beta$-glucuronidase gene in hypocotyls of rapeseed microspore-derived embryos. Biologia Plantarum, 53, 573-577. doi:10.1007/s10535-009-0104-1

Able, J. A., Rathus, C., \& Godwin, I. D. (2001). The investigation of optimal bombardment parameters for transient and stable transgene expression in Sorghum. In Vitro Cellular \& Developmental Biology-Plant, 37, 341-348. doi:10.1007/s11627-001-0061-7

Campbell, M. M., Brunner, A. M., Jones, H. M., \& Strauss, S. H. (2003). Forestry's fertile crescent: The application of biotechnology to forest trees. Plant Biotechnology Journal, 1, 141-154. doi:10.1046/j.1467-7652.2003.00020.x

Casas, A. M., Kononowicz, A. K., Zher, U. B., Tomes, D. T., Axtell, J. D., Butler, L. G., Bressan, R. A., \& Hasegawa, P. M. (1993). Transgenic sorghum plants via microprojectile bombardment. Proceedings of the National Academy of Sciences USA, 90, 11212-11216. doi:10.1073/pnas.90.23.11212

Catlin, D. W. (1990). The effect of antibiotics on the inhibition of callus induction and plant regeneration from cotyledons of sugarbeet
(Beta vulgaris L.). Plant Cell Reports, 9, 285-288. doi:10.1007/BF00232303

Drewinko, B., Freireich, E. J., \& Gottlieb, J. A. (1974). Lethal activity of camptothecin sodium on human lymphoma cells. Cancer Research, 34, 747-750

Duke, S. O. (1996). Herbicide-resistant crops: Agricultural, environmental, economic, regulatory, and technical aspects. Boca Raton, FL: CRC Press.

Elliott, A. R., Campbell, J. A., Dugdale, B., Brettel, R. I. S., \& Grof, C. P. L. (1999). Green-fluorescent protein facilitates rapid in vivo detection of genetically transformed plant cells. Plant Cell Reports, 18, 707-714. doi: 10.1007/s002990050647

Geier, T., Eimert, K., Scherer, R., \& Nickel, C. (2008). Production and rooting behaviour of rol B-transgenic plants of grape rootstock 'richter 110' (Vitis berlandieri $\times V$. rupestris). Plant Cell, Tissue and Organ Culture, 94, 269-280. doi:10.1007/s11240-008-9352-6

Giri, C. C., Shyamkumar, B., \& Anjaneyulu, C. (2004). Progress in tissue culture, genetic transformation and applications of biotechnology to trees: An overview. Trees, 18, 115-135. doi:10.1007/s00468-003-0287-6

Heim, R., \& Tsien, R. (1996). Engineering green fluorescent protein for improved brightness, longer wavelengths and fluorescence resonance energy transfer. Current Biology, 6, 178-182. doi:10.1016/S0960-9822(02)00450-5

Hunold, R., Bronner, R., \& Hahne, G. (1994). Early events in microprojectile bombardment: Cell viability and particle location. The Plant Journal, 5, 593-604. doi:10.1046/j.1365-313X.1994.5040593.x

Ikea, J., Ingelbrecht, I., Uwaifo, A., \& Thottappilly, G. (2003). Stable gene transformation in cowpea (Vigna unguiculata L. walp.) using particle gun method. African Journal of Biotechnology, 2, 211-218.

Jefferson, R. A., Kavanagh, T. A., \& Bevan, M. W. (1987). GUS fusion: $\beta$-glucuronidase as a sensitive and versatile gene fusion marker in higher plants. The EMBO Journal, 6, 3901-3907.

Jeoung, J. M., Krishnaveni, S., Muthukrishnan, S., Trick, H. N., \& Liang, G. H. (2003). Optimization of sorghum transformation parameters using genes for green fluorescent protein and $\beta$-glucuronidase as visual markers. Hereditas, 137, 120-128.

Klein, T. M., \& Jones, T. J. (1999). Methods of genetic transformation: The gene gun. In: I. K. Vasil (Ed.), Molecular improvement of cereal crops (pp. 21-42). The Netherlands: Kluwer Academic Publishers. doi:10.1007/978-94-011-4802-3 3

Merkle, S. A., \& Nairn, C. J. (2005). Hardwood tree biotechnology. In Vitro Cellular \& Developmental Biology_Plant, 41, 602-619. doi:10.1079/IVP2005687

Morimoto, M., Nakamura, K., \& Sano, H. (2006). Regeneration and genetic engineering of a tropical tree Azadirachta excelsa. Plant Biotechnology, 23, 123-127. doi:10.5511/plantbiotechnology.23.123

Murashige, T., \& Skoog, F. (1962). A revised medium for rapid growth and bioassays with tobacco tissue cultures. Physiologia Plantarum, 15, 473-497. doi:10.1111/i.1399-3054.1962.tb08052.x

Okumura, S., Sawada, M., Park, Y. W., Hayashi, T., Shimamura, M., Takase, H., \& Tomizawa, K. I. (2006). Transformation of poplar (Populus alba) plastids and expression of foreign proteins in tree chloroplasts. Transgenic Research, 15, 637-646. doi:10.1007/s11248-006-9009-3

Parveez, G. K. A., Chowdhury, M. K. U., \& Saleh, N. M. (1997). Physical parameters affecting transient GUS gene expression in oil palm (Elaeis guineensis Jacq.) using the biolistic device. Industrial Crops and Products, 6, 41-50. doi:10.1016/S0926-6690(96)00204-X

Peña-Ramírez, Y. J., García-Sheseña, I., Hernández-Espinoza, A., Domínguez-Hernández, A., Barredo-Pool, F. A., González- Rodríguez, J. A., \& Robert, M. L. (2011). Induction of somatic embryogenesis and plant regeneration in the tropical timber tree Spanish red cedar [Cedrela odorata L. (Meliaceae)]. Plant Cell, Tissue and Organ Culture, 105, 203-209. doi:10.1007/s11240-010-9853-y

Pérez-Barranco, G., Torreblanca, R., Padilla, I. M. G., Sánchez-Romero, C., Pliego-Alfaro, F., \& Mercado, J. A. (2009). Studies on genetic transformation of olive (Olea europaea L.) somatic embryos: I. Evaluation of different aminoglycoside antibiotics for nptII selection; II. transient transformation via particle bombardment. Plant Cell, Tissue and Organ Culture, 97, 243-251. 
doi:10.1007/s11240-009-9520-3

Pérez-Salicrup, D. R., \& Esquivel, R. (2008). Tree infection by Hypsipyla grandella in Swietenia macrophylla and Cedrela odorata (Meliaceae) in Mexico's southern Yucatan Peninsula. Forest Ecology and Management, 255, 324-327.

Rasco-Gaunt, S., Riley, A., Barcelo, P., \& Lazzeri, P. A. (1999). Analysis of particle bombardment parameters to optimise DNA delivery into wheat tissues. Plant Cell Reports, 19, 118-127. doi:10.1007/s002990050721

Rothrock, R. E., Polin-McGuigan, L. D., Newhouse, A. E., Powell, W. A., \& Maynard, C. A. (2007). Plate flooding as an alternative Agrobacterium-mediated transformation method for American chestnut somatic embryos. Plant Cell, Tissue and Organ Culture, 88, 93-99. doi:10.1007/s11240-006-9170-7

Sanford, J. C., Smith, F. D., \& Russell, J. A. (1993). Optimizing the biolistic process for different biological applications. Methods in Enzymology, 217, 483-509. doi:10.1016/0076-6879(93)17086-K

Sartoretto, L. M., Cid, L. P. B., \& Brasileiro, A. C. M. (2002). Biolistic transformation of Eucalyptus grandis $\times$ E. urophylla callus. Func- tional Plant Biology, 29, 917-924. doi:10.1071/PP01153

Schöpke, C., Taylor, N. J., Cárcamo, R., Beachy, R. N., \& Fauquet, C. (1997). Optimization of parameters for particle bombardment of embryogenic suspension cultures of cassava (Manihot esculenta Crantz) using computer image analysis. Plant Cell Reports, 16, 526-530.

Tadesse, Y., Sági, L., Swennen, R., \& Jacobs, M. (2003). Optimisation of transformation conditions and production of transgenic sorghum (Sorghum bicolor) via microparticle bombardment. Plant Cell, Tissue and Organ Culture, 75, 1-18. doi:10.1023/A:1024664817800

Tee, C. S., \& Maziah, M. (2005). Optimization of biolistic bombardment parameters for Dendrobium Sonia 17 calluses using GFP and GUS as the reporter system. Plant Cell, Tissue and Organ Culture, 80, 77-89. doi:10.1007/s11240-004-9144-6

Zuker, A., Chang, P. F. L., Ahroni, A., Cheah, K., Woodson, W. R., Bressan, R. A., Watad, A. A., Hasegawa, P. M., \& Vainstein, A. (1995). Transformation of carnation by microprojectile bombardment. Scientia Horticulturae, 64, 177-185. doi:10.1016/0304-4238(95)00817-9 